\title{
MANAJEMEN TEMPAT TUMBUH PADA TANAMAN Eucalyptus pellita DI PT. PERAWANG SUKSES PERKASA INDUSTRI, DISTRIK LIPAT KAIN, RIAU
}

\author{
Site Management Eucalyptus pellita at PT. Perawang Sukses Perkasa Industri, Riau \\ Prijanto Pamoengkas dan Puspita Laksmi Maharani
}

(Diterima Maret 2016 / Disetujui Februari 2018)

\begin{abstract}
Eucalyptus sp. is species which the developed in forest plantation of Indonesia as wood fiber plantation. Wood fiber for pulp and paper is important, so we need to know management of site to obtain the optimal growth of Eucalyptus pellita at PT. Perawang Sukses Perkasa Industri (PSPI). The aim of the research was to observe fertilization management and maintenance management at PT. PSPI. This research used Forest Health Monitoring (FHM) method to take data of plant growth. The cluster had 4 plot. The sample was E. pellita 1-4 years. Fertilization management at PT PSPI were basic fertilizer (CIRP/Cristmast Island Rock Phosphate and NPK) and supplementary fertilizer (NPK-1, NPK2, NPK-3). Maintenance Management at PT. PSPI were ring weeding, sport spray of herbicide and slash. Maintenancing and fertilizing were given to the plot according to the environmental conditions and the age factor. The best growth increment was in plot P2. P2 had 4.14 diameter increment and 5.72 height increment.
\end{abstract}

Keywords: Eucalyptus pellita, Forest Health Monitoring, Industrial forest, site management, maintenance management, fertilization management

\section{PENDAHULUAN}

Eucalyptus sp. merupakan salah satu jenis prioritas yang dikembangkan dalam pengelolaan HTI yang diperuntukkan sebagai kayu serat. Kriteria jenis yang dipilih untuk hutan tanaman pulp, yaitu jenis cepat tumbuh, produktivitas tinggi, daur pendek dan memiliki sifat (kimia dan fisika) kayu sesuai dengan persyaratan bahan baku industri pulp (Mindawati 2010). Kayu pulp harus memiliki serat yang panjang, kandungan lignin yang relatif rendah, rendemen yang tinggi serta kekuatan pulp dan kertas yang dihasilkan tinggi (Pasaribu dan Tampubolon 2007). Eucalyptus sp. cocok dikembangkan di daerah tropis (Leksono 2010), dipanen pada umur 6-7 tahun (Quilho 2006), dan layak untuk bahan baku pulp pada umur 4-5 tahun (Sihite 2008).

Salah satu jenis Eucalyptus sp. yang dikembangkan adalah jenis Eucalyptus pellita. Jenis ini merupakan salah satu spesies endemik Indonesia yang tumbuh di Papua sampai dengan ketinggian di atas $800 \mathrm{mdpl}$.

Beberapa faktor yang mempengaruhi keberhasilan HTI adalah tercapainya hasil produksi yang tinggi. Tingginya produksi berhubungan erat dengan faktor manajemen tempat tumbuh. Manajemen tempat tumbuh sangat mempengaruhi produktivitas. Oleh karena itu, penelitian untuk mengetahui manajemen tempat tumbuh terhadap tanaman E. pellita ini dilakukan di PT. Perawang Sukses Perkasa Industri (PSPI). PT. PSPI ditunjuk sebagai lokasi penelitian karena PT. PSPI

Departemen Silvikultur, Fakultas Kehutanan, IPB merupakan salah satu perusahaan penyuplai kayu untuk bahan baku pulp and paper dengan tanaman pokoknya adalah E. pellita.

Penelitian ini bertujuan untuk mengetahui manajemen yang dilakukan pada tempat tumbuh terhadap pertumbuhan tanaman E. pellita di PT. PSPI.

\section{METODE PENELITIAN}

\section{Waktu dan Tempat}

Penelitian ini dilaksanakan dari tanggal 1 Maret sampai 14 April 2014 di IUPHHK-HTI PT. Perawang Sukses Perkasa Industri.

\section{Alat dan Bahan}

Alat yang digunakan adalah peta petak penelitian $E$. pellita umur 1-4 tahun, GPS, kompas, meteran, tali tambang, phiband, Vertex, Transponden, penggaris, parang, pita, densiometer, alat tulis, tally sheet, kertas, kamera, laptop, MS. Excel. Bahan yang digunakan adalah tanaman E. pellita umur 1-4 tahun.

\section{Prosedur Penelitian}

\section{Tahap Persiapan Penelitian}

Tahap persiapan penelitian manajemen tempat tumbuh ada beberapa tahap yaitu, penentuan petak, cluster dan plot penelitian tegakan E. pellita umur 1-4 tahun, studi pustaka tentang penelitian dan kondisi lapang di PT. PSPI, latihan dalam penggunaan alat dan 
cara membaca peta yang benar, serta mencari informasi tentang lokasi penelitian. Metode yang digunakan dalam penelitian ini adalah metode Forest Health Monitoring (FHM). Pada metode ini terdapat satu cluster dengan 4 plot di dalamnya.

\section{Tahap Pengambilan Data}

Data yang diambil merupakan data diameter, tinggi dan kerapatan tajuk tegakan E. pellita dari umur 1-4 tahun pada cluster yang ditetapkan untuk penelitian manajemen tempat tumbuh.

\section{Analisis Data}

\section{Riap rata-rata tahunan (MAI) diameter pohon}

Riap rata-rata tahunan diameter ini mengacu pada rumus riap tahunan rata-rata/ Mean Annual Increment (MAI). Rumus riap tahunan rata-rata tersebut adalah sebagai berikut,

Ket :

$$
I d_{i}=d_{i} / d t
$$

$I d_{i}$ : riap diameter rata-rata pada tahun ke-i (cm/tahun)

$d_{i}$ : diameter pohon rata-rata pada tahun ke-i $(\mathrm{cm})$

$t_{i} \quad$ : umur pohon rata-rata pada tahun ke-i (tahun)

\section{Riap rata-rata tahunan (MAI) tinggi pohon}

Riap rata-rata tahunan tinggi ini mengacu pada rumus riap tahunan rata-rata (MAI). Rumus riap tahunan rata-rata tersebut adalah sebagai berikut,

Ket :

$$
I h_{i}=h_{i} / t_{i}
$$

$I h_{i}$ : riap tinggi rata-rata pada tahun ke-i (cm/tahun)

$h_{i} \quad$ : tinggi pohon rata-rata pada tahun ke-i $(\mathrm{cm})$

$t_{i}$ : umur pohon rata-rata pada tahun ke-i (tahun)

\section{Distribusi kelas diameter dan tinggi}

Analisis distribusi kelas diameter dan tinggi menggunakan Ms. Excel 2007 dengan mengurutkan data dari yang terkecil ke yang terbesar, untuk mempermudah pengolahan data. Kemudian untuk menentukan jumlah kelas $(k)$ menggunakan rumus Sturges $(k)=1+3.3 \log \mathrm{n}$, dan untuk menentukan range ( $r$ ) yaitu dengan menggunakan rumus range $(r)=\mathrm{X}_{\mathrm{k}}-$ $\mathrm{X}_{1}$, dengan ketentuan $\mathrm{X}_{\mathrm{k}}$ adalah data terbesar dan $\mathrm{X}_{1}$ adalah data terkecil, dan menentukan interval kelas adalah dengan rumus, interval kelas $(i)=(r) /(k)$. Frekuensi dihitung dengan cara menghitung jumlah data pada setiap kelas (Mutia 2013).

\section{HASIL DAN PEMBAHASAN}

\section{Kondisi Umum Lokasi Penelitian}

PT. PSPI merupakan perusahaan yang disahkan berdasarkan SK IUPHHK-HTI Nomor 249/Kpts-II/1998 tanggal 27 Pebruari 1998 dengan luas area konsesi 50 725 Ha. PT. PSPI terbagi menjadi dua distrik yaitu Distrik Lipat Kain seluas $30700 \mathrm{Ha}$ (Blok I seluas 24 022 Ha dan Blok II seluas $6678 \mathrm{Ha}$ ) dan Distrik Batu Telangkah, Petapahan seluas $20025 \mathrm{Ha}$.
Penelitian manajemen tempat tumbuh terhadap tanaman E. pellita dilaksanakan di PT. PSPI Distrik Lipat Kain yaitu pada topografi yang sangat bervariasi yaitu topografi datar $(0 \%-8 \%)$ seluas $23523 \mathrm{Ha}$, landai $(8 \%-15 \%)$ seluas $6145 \mathrm{Ha}$, agak curam $(15 \%-25 \%)$ seluas $1032 \mathrm{Ha}$. Jenis tanahnya adalah tanah mineral yaitu jenis Podsolik Merah Kuning dan Organosol. Seluruh kawasan PT. PSPI Distrik Lipat Kain memiliki tipe iklim A (Schmidt \& Ferguson). Curah hujan ratarata tahunan mencapai $3343.3 \mathrm{~mm} /$ tahun.

\section{Kualitas Tapak}

Kualitas tapak tanah dapat dinilai dari tebal serasah, keasaman tanah, kapasitas tukar kation, tekstur dan struktur tanahnya. Foth dan Ellis (1997), mendefinisikan kesuburan tanah sebagai status yang menunjukkan kapasitas untuk memasok unsur-unsur esensial dalam jumlah yang mencukupi pertumbuhan tanaman. Data tanah dari petak penelitian dapat dilihat pada Tabel 1 .

Tabel 1 Data tanah di petak tegakan E. pellita umur 1-

\begin{tabular}{|c|c|c|c|c|c|}
\hline \multirow[b]{2}{*}{ Petak } & \multicolumn{5}{|c|}{ Tanah } \\
\hline & Struktur & Tekstur & $\mathrm{pH}$ & KTK & $\begin{array}{c}\text { Serasah } \\
(\mathrm{cm})\end{array}$ \\
\hline P1 & Granular & $\begin{array}{l}\text { Pasir } \\
\text { berlempung } \\
\text { (loamy } \\
\text { sand) }\end{array}$ & 4.2 & Rendah & 4 \\
\hline $\mathrm{P} 2$ & Granular & $\begin{array}{l}\text { Pasir } \\
\text { berlempung }\end{array}$ & 4.2 & Rendah & 5 \\
\hline P3 & Granular & $\begin{array}{l}\text { Pasir } \\
\text { berlempung }\end{array}$ & 4.3 & Rendah & 4.8 \\
\hline P4 & Granular & $\begin{array}{l}\text { Pasir } \\
\text { berlempung }\end{array}$ & 4.5 & Rendah & 6.9 \\
\hline
\end{tabular}
4 tahun

Sumber : Laporan pelaksanaan izin lingkungan PT PSPI 2014

Keterangan: Huruf $\mathrm{P}$ menandakan petak, angka yang mengikuti huruf $\mathrm{P}$ menandakan umur

Secara umum, pH dan KTK tanah pada lokasi penelitian adalah rendah dengan tekstur pasir berlempung dan struktur granular, sedangkan kondisi serasahnya berkisar antara 4-6.9 $\mathrm{cm}$. Kondisi serasah mempengaruhi proses dekomposisi, sedangkan proses dekomposisi dipengaruhi oleh beberapa faktor diantaranya adalah Oksigen, bakteri dan bahan organik.

\section{Kerapatan Tajuk}

Kerapatan tegakan menentukan kerapatan tajuk dalam hutan. Hutan yang dikelola dengan baik, kerapatan tegakan akan terjaga sehingga tegakan yang ada dapat memanfaatkan sinar matahari, air dan zat hara mineral dalam tanah. Kondisi tajuk yang terbuka akan mempermudah masuknya cahaya matahari sehingga mendukung pertumbuhan gulma yang dapat mengganggu pertumbuhan jenis pohon utama.

Fotosintesis tegakan dalam lingkungan harus memperhitungkan masalah kompleks ketersediaan cahaya dalam tajuk pohon dan perubahan cahaya serta lama penyinaran harian dan musiman. Intensitas cahaya sangat mempengaruhi kecepatan fotosintesis sedangkan lama penyinaran mempengaruhi karbohidrat yang diproduksi. 
E. pellita merupakan jenis tanaman yang bersifat intoleran yaitu tanaman yang dapat tumbuh dengan baik tanpa tanaman penaung, sehingga cahaya matahari secara leluasa dapat diterima tajuk E. Pellita. E. Pellita memiliki bentuk tajuk yang sedikit ramping dan ringan, percabangannya membentuk kerucut dan daunnya tidak begitu lebat (Muliawan 2009).

Kerapatan tajuk yang diperoleh dari petak penelitian yaitu pada petak P1 sebesar 52.4\%; P2, 60.7\%; P3, $56.6 \%$; dan P4 sebesar 59.9\%. Pada petak penelitian terlihat bahwa kerapatan tajuk tertinggi adalah pada petak P2 yaitu $60.7 \%$, petak P1 merupakan petak yang memiliki kerapatan tajuk terendah yaitu $52.37 \%$. Hal ini disebabkan banyak tanaman yang mati sehingga cahaya yang masuk sedikit lebih banyak jika dibandingkan dengan petak penelitian lainnya.

Kadri et al. (1992), membedakan tegakan hutan berdasarkan kerapatan tajuk yaitu,

a. Tegakan hutan rapat, yaitu tegakan yang penutupan tajuknya lebih dari $70 \%$.

b. Tegakan hutan cukup, yaitu tegakan hutan yang penutupan tajuknya 40-70\%.

c. Tegakan hutan jarang, yaitu tegakan hutan yang penutupan tajuknya kurang dari $40 \%$.

Sesuai dengan data yang diperoleh dari petak penelitian, maka dapat dikatakan bahwa petak-petak penelitian termasuk ke dalam tegakan hutan cukup pencahayaan karena kerapatan tajuknya berkisar antar $52.4 \%$ sampai $60.7 \%$.

\section{Manajemen Tempat Tumbuh}

Manajemen tempat tumbuh merupakan pengelolaan terhadap tempat tumbuh suatu tanaman. Pengelolaan tempat tumbuh yang baik perlu dilakukan karena pada HTI, kualitas tempat tumbuh terus mengalami penurunan hal ini terjadi akibat erosi, angin dan air hujan. Pada dasarnya pertumbuhan tanaman akan didukung oleh kualitas tapak yang baik dan bibit yang berkualitas, bibit yang digunakan di PT. PSPI adalah bibit yang berasal dari Research and Development (R\&D) yang berlokasi di Perawang, Riau. Kualitas tempat tumbuh dapat dilihat dari tinggi tegakan. Tegakan akan tumbuh lebih besar pada tempat tumbuh yang subur dari pada tempat tumbuh yang jelek dan miskin hara (Indriyanto 2010). Pupuk dasar diberikan bersamaan pada waktu tanam, pupuk yang digunakan yaitu NPK (150 gram/batang) dan CIRP (300 gram/batang). CIRP adalah pupuk fosfor berbentuk butiran halus yang memiliki kandungan $\mathrm{P}_{2} \mathrm{O}_{5}$ berkisar antara $32 \%$ hingga $36 \%$. Pupuk susulan yang diberikan adalah pupuk NPK. Manajemen pemupukan di PT PSPI dapat dilihat pada Tabel 2.

Tabel 2 Manajemen pemupukan pada petak penelitian E. pellita umur 1-4 tahun.

\begin{tabular}{lrrrrr}
\hline & \multicolumn{2}{c}{ Pupuk Dasar } & \multicolumn{3}{c}{ Pupuk Susulan } \\
\hline Petak & $\begin{array}{c}\text { CIRP } \\
(\mathrm{g} / \mathrm{btg})\end{array}$ & $\begin{array}{c}\text { NPK } \\
(\mathrm{g} / \mathrm{btg})\end{array}$ & $\begin{array}{l}\text { NPK 1 } \\
(\mathrm{g} / \mathrm{btg})\end{array}$ & $\begin{array}{l}\text { NPK 2 } \\
(\mathrm{g} / \mathrm{btg})\end{array}$ & \multicolumn{1}{l}{$\begin{array}{l}\text { NPK 3 } \\
(\mathrm{g} / \mathrm{btg})\end{array}$} \\
\hline P1 & 300 & 150 & 150 & 0 & 0 \\
P2 & 300 & 150 & 150 & 200 & 0 \\
P3 & 300 & 150 & 150 & 200 & 250 \\
P4 & 300 & 150 & 100 & 100 & 250 \\
\hline
\end{tabular}

Sumber : Dokumen Laporan Kerja Plantation PT. PSPI
Berdasarkan tabel 3 terlihat adanya pemberian pupuk dasar CIRP, pupuk ini merupakan pupuk yang mengandung Fosfor. Pemberian pupuk dasar NPK dan CIRP adalah pada saat penanaman. Pupuk CIRP dimasukkan ke dalam lubang tanam kemudian ditutup dengan top soil, setelah itu lubang ditugal lagi untuk menanam bibit. Pupuk NPK dimasukkan ke dalam lubang yang telah disediakan khusus untuk pupuk NPK yaitu di kanan dan kiri tanaman dengan jarak $15 \mathrm{~cm}$ dari tanaman. Pupuk susulan NPK diberikan di antara 2 tanaman yang tingginya $>30 \mathrm{~cm}$.

PT. PSPI juga melakukan kegiatan buka piringan, penyemprotan herbisida dan pembabatan. Buka piringan bertujuan untuk meminimalisir tumbuhnya gulma di sekitar tanaman dan mempermudah kegiatan penyemprotan herbisida. Pembabatan biasanya dilakukan ketika gulma tingginya sudah lebih dari $1 \mathrm{~m}$. Kegiatan penyemprotan herbisida, pembabatan dan buka piringan dapat dilihat pada tabel 3 .

Tabel 3. Manajemen pemeliharaan tanaman

\begin{tabular}{cccc}
\hline Petak & $\begin{array}{r}\text { Penyemprotan } \\
\text { Gulma }\end{array}$ & $\begin{array}{c}\text { Babat } \\
\text { Gulma }\end{array}$ & $\begin{array}{c}\text { Buka } \\
\text { Piringan }\end{array}$ \\
\hline P1 & 4 kali & 0 & 1 kali \\
P2 & 5 kali & 1 kali & 1 kali \\
P3 & 5 kali & 1 kali & 1 kali \\
P4 & 6 kali & 2 kali & 1 kali \\
\hline
\end{tabular}

Sumber : Dokumen Laporan Kerja Plantation PT PSPI

Tabel 3 menjelaskan bahwa buka piringan dilakukan pada setiap tanaman. Buka piringan dilakukan diawal sebelum kegiatan penyemprotan herbisida pertama dilakukan. Buka piringan dilakukan untuk memperkecil angka kematian tanaman akibat keracunan herbisida. Penyemprotan dilakukan di areal tanam yang terdapat banyak gulma dengan penutupan gulma $\geq 10 \%$, kecuali untuk alang-alang, penyemprotan wajib dilakukan meskipun gulmanya $<10 \%$. Hal ini menyebabkan jumlah penyemprotan herbisida di setiap petak penelitian tidak sama.

\section{Pertumbuhan $E$. pellita}

E. pellita dapat tumbuh pada tanah yang dangkal, berbatu-batu, lembah, berawa, dengan variasi kesuburan tanah mulai dari yang mempunyai kandungan hara kurang sampai tanah yang baik dan subur (Muliawan 2009).

Pertumbuhan tanaman dipengaruhi oleh dua faktor yaitu faktor eksternal (lingkungan) dan faktor internal (genetik). Faktor eksternal meliputi iklim (cahaya, temperatur, air, panjang hari, angin dan gas), edafis/tanah (tekstur, struktur, bahan organik, kapasitas tukar kation, $\mathrm{pH}$, kejenuhan basa, dan ketersediaan nutrien), dan biologi (gulma, serangga, organisme penyebab penyakit nematoda, herbivora dan mikroorganisme). Faktor internal meliputi ketahanan terhadap tekanan iklim, tanah dan biologis, laju fotosintetis, respirasi, pembagian asimilasi dan $\mathrm{N}$, pengaruh langsung gen dan diferensiasi. Hasil pengamatan pertumbuhan tanaman E. pellita dapat dilihat pada Tabel 4 . 
Tabel 4 Pertumbuhan E. pellita

\begin{tabular}{ccrrrrr}
\hline & & \multicolumn{2}{c}{ Rata-rata } & \multicolumn{2}{c}{ Riap tahunan rata-rata } & \\
\cline { 3 - 6 } Petak & Umur (tahun) & $\begin{array}{c}\text { Diameter } \\
(\mathrm{cm})\end{array}$ & Tinggi $(\mathrm{m})$ & $\begin{array}{c}\text { Diameter } \\
(\mathrm{cm} / \text { tahun })\end{array}$ & $\begin{array}{c}\text { Tinggi } \\
(\mathrm{m} / \text { tahun })\end{array}$ & $\Sigma$ Sampel \\
\hline P1 & 1 & 6.65 & 7.85 & 6.65 & 7.85 & 501 \\
P2 & 2 & 8.79 & 12.13 & 4.36 & 6.02 & 482 \\
P3 & 3 & 10.47 & 17.34 & 3.48 & 5.77 & 510 \\
P4 & 4 & 9.55 & 17.38 & 2.38 & 4.34 & 512 \\
\hline
\end{tabular}

Tabel 4, menunjukkan rata-rata pertumbuhan dan rata-rata riap (MAI) E. pellita pertahun tanam. Pertumbuhan diameter tertinggi adalah pada petak P3 yaitu $10.47 \mathrm{~cm}$ sedangkan terendah adalah pada petak P1 yaitu $6.65 \mathrm{~cm}$. Pertumbuhan tinggi tegakan yang tertinggi adalah pada petak $\mathrm{P} 4$ yaitu $17.38 \mathrm{~m}$ dan terendah pada petak P1 yaitu $7.85 \mathrm{~m}$. Pertumbuhan riap MAI diameter dan tinggi yang tertinggi adalah pada petak P1, sedangkan yang terendah adalah pada petak P4.

\section{Kurva Pertumbuhan}

Kurva pertumbuhan tanaman secara khas dicirikan oleh suatu kurva yang berbentuk sigmoid. Pola kumpulan sigmoid merupakan ciri semua organisme, organ, jaringan dan bahkan penyusun sel. Apabila masa pertumbuhan (berat kering), volume, luas daun dan penimbunan bahan kimia digambarkan terhadap waktu, suatu garis yang dapat ditarik dari data secara normal akan berbentuk sigmoid. Kurva berbentuk $S$ akan terbentuk karena adanya laju pertumbuhan sepanjang daur hidupnya (Mutia 2013). Kurva pertumbuhan E. pellita dapat dilihat pada Gambar 1.

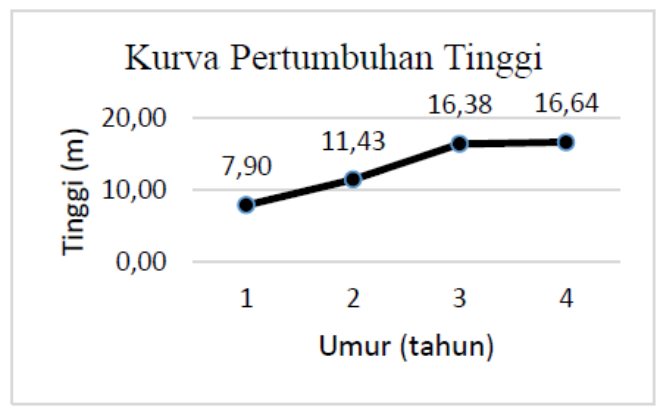

(a)

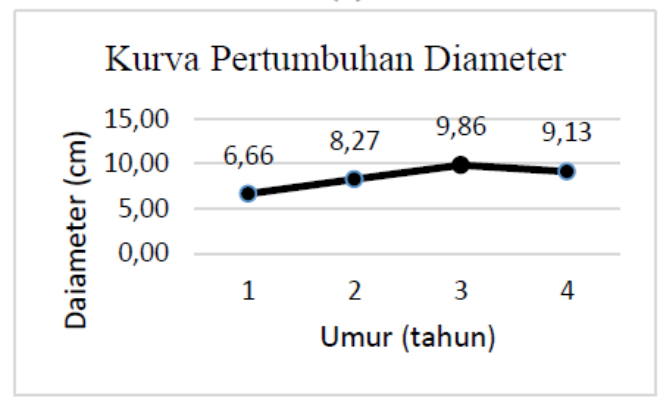

(b)

Gambar 1 Kurva pertumbuhan E. pellita (a) diameter (b) tinggi

Gambar 1 menjelaskan bahwa pertumbuhan $E$. pellita terus mengalami peningkatan dari umur 1-3 tahun, meskipun terjadi penurunan pada tanaman yang berumur 4 tahun. Hal ini diduga karena perbedaan pemberian konsentrasi pupuk susulan NPK yang berbeda.

\section{Distribusi Kelas Diameter dan Tinggi}

Bentuk sebaran diameter dan tinggi tegakan seumur akan menyerupai lonceng telungkup, yaitu mendekati sebaran normal yang dapat miring ke arah diameter yang lebih kecil untuk jenis toleran dan diameter yang besar untuk jenis intoleran. Struktur tegakan hutan pada hutan tanaman merupakan sebaran jumlah pohon per hektar pada berbagai kelas umur. Bentuk sebaran ini akan menyerupai lonceng telungkup yaitu mendekati sebaran normal (Daniel et al. 1987). Kurva sebaran tinggi dapat dilihat pada gambar 2.

Berdasarkan data yang diperoleh persebaran tinggi tanaman sesuai dengan pendapat Daniel (1987) yang mengatakan bahwa bentuk kurva persebaran itu berbentuk lonceng, dan untuk tanaman intoleran kurva akan lebih condong kearah tinggi dan diameter yang lebih besar. Pada P1 dan P2 kurvanya berbentuk normal sedangkan kurva pada P3 dan P4 lebih berat kekanan, ke arah tinggi yang lebih besar. Hal ini juga terjadi pada kurva persebaran diameter yang dapat dilihat pada gambar 3.

Bentuk kurva pada penyebaran diameter yang terlihat pada gambar 3, persebaran diameter tegakan $E$. pellita umur 3 dan 4 tahun adalah normal sedangkan pada umur 1 dan 2 tahun kurvanya berat kesebelah kanan. Hal ini sesuai dengan pernyataan Daniel et al (1987), bahwa persebaran diameter pada tanaman intoleran berbentuk lonceng terbalik dan lebih berat kearah diameter yang lebih besar.

\section{Hubungan Manajemen Tempat Tumbuh dengan Pertumbuhan $E$. pellita}

Manajemen yang diberikan pada setiap tempat tumbuh berbeda-beda hal ini dipengaruhi oleh faktor umur dan kondisi petak penelitian. Kualitas dari tempat tumbuh itu sendiri juga memberi pengaruh yang besar pada pertumbuhan tanaman. Dari lokasi penelitian kondisi tanah secara umum adalah sama yaitu dengan struktur tanah yang berbentuk granular, tekstur pasir berlempung (loamy sand) memiliki $\mathrm{pH}$ kisaran 4-4.8 dan memiliki KTK rendah. Ketika pH dan KTK rendah, maka akan berdampak pada unsur hara tanaman.

Menurut Barros et al. (1990), tanaman E. pellita merupakan tanaman yang jarang menanggapi N. N organik utama adalah yang berasal dari mineralisasi bahan organik selama rotasi cukup untuk memenuhi kebutuhan hara tegakan (Goncalves \& Barros 1999). Namun karena output $\mathrm{N}$ tinggi, maka tegakan E. pellita sering kekurangan N. Oleh karena itu, hutan yang dikelola secara intensif biasanya baru dapat menanggapi $\mathrm{N}$ setelah adanya pemupukan yang diberikan setelah rotasi berturut-turut (Bellote et al. 1980). 


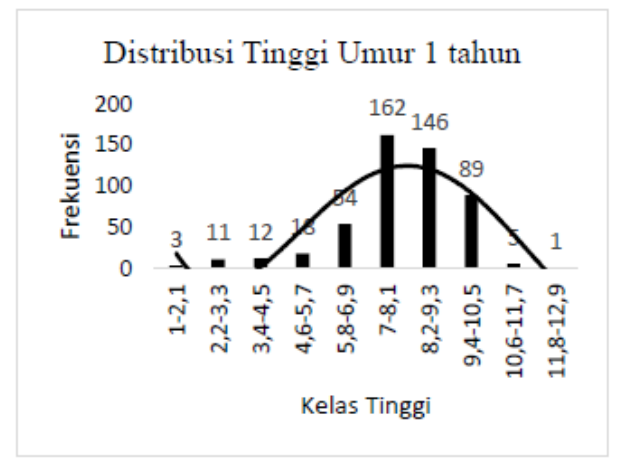

(a)

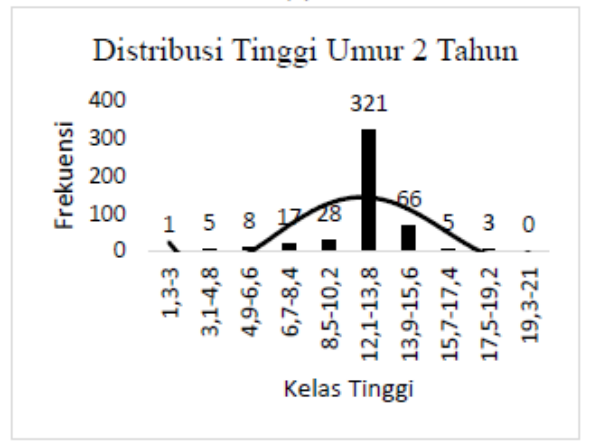

(b)

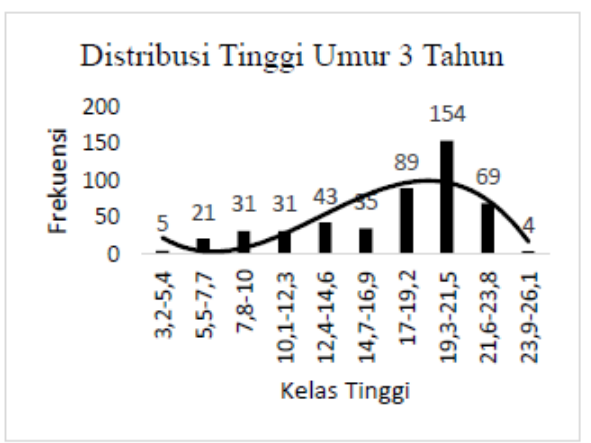

(c)

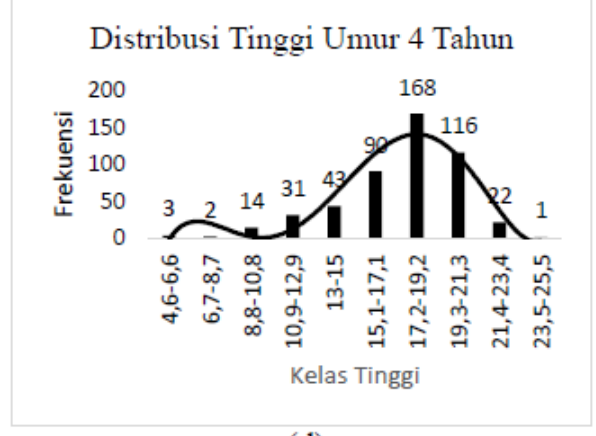

(d)

Gambar 2 Distribusi kelas tinggi (a) P1 (b) P2 (c) P3 (d) P4

Ketebalan serasah yang berbeda-beda yaitu petak P1 setebal $4 \mathrm{~cm}, \mathrm{P} 2$ setebal $5 \mathrm{~cm}, \mathrm{P} 3$ setebal $4.8 \mathrm{~cm}$ dan P4 setebal $6.9 \mathrm{~cm}$ memberikan pengaruh pada tanaman. Menurut penelitian Aprianis (2010), serasah dapat menambah masukan hara dalam bentuk $\mathrm{N}, \mathrm{Ca}, \mathrm{Mg}, \mathrm{P}$ dan K. Jumlah unsur hara ini akan mensubsidi ke dalam tanah apabila serasah tersebut telah terdekomposisi semua.

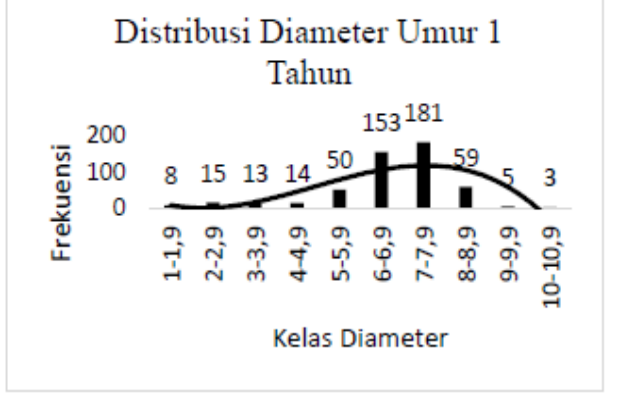

(a)

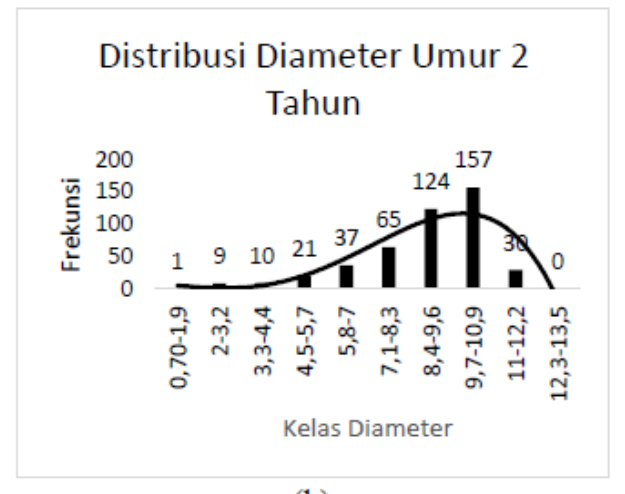

(b)

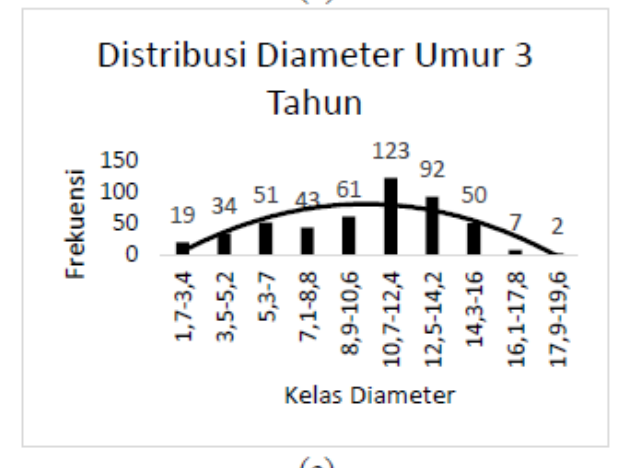

(c)

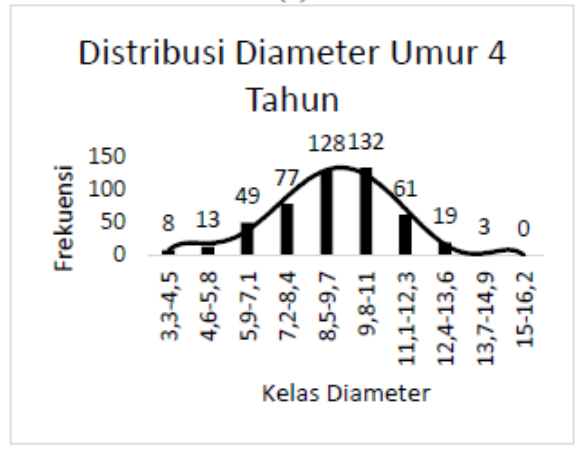

(d)

Gambar 3 Distribusi Diameter (a) P1 (b) P2 (c) P3 (d) P4

Pemberian pupuk NPK juga memberikan pengaruh pada tanaman, dari tanaman P1, P2, P3 dan P4, baru tanaman P3 dan P4 saja yang sudah mendapatkan pupuk susulan NPK 3 kali, akan tetapi konsentrasi yang diberikan berbeda-beda, pada pupuk susulan 1, konsentrasi yang diberikan adalah $150 \mathrm{~g} / \mathrm{batang}$, pupuk susulan 2, 200g/batang dan susulan 3, $250 \mathrm{~g} / \mathrm{batang}$, sedangkan pada petak $\mathrm{P} 4$, pupuk susulan 1 dan 2 konsentrasinya adalah 100 g/batang dan susulan 3, 250 g/batang. Hal ini memberikan pengaruh pada diameter dan tinggi tanaman, tanaman pada P3 lebih baik 
dibandingkan tanaman $\mathrm{P} 4$. Hal ini disebabkan $\mathrm{pH}$ tanah mempengaruhi keberadaan unsur hara pada tanaman.

Buka piringan juga mempengaruhi persentase hidup tanaman, kematian sering kali disebabkan tanaman keracunan akibat tersemprot herbisida. Buka piringan dilakukan untuk meminimalisir terjadinya kematian akibat tanaman tersemprot herbisida. Gulma juga merupakan saingan dalam pengambilan unsur hara dan nutrisi yang dibutuhkan tanaman. Semprot herbisida dilakukan sesuai dengan kondisi gulma pada petak tersebut. Semprot herbisida perlu dilakukan agar tanaman pokok dapat menyerap unsur hara dan nutrisi secara optimal. Babat memiliki tujuan yang sama dengan semprot herbisida akan tetapi babat baru dilakukan ketika tinggi gulma mencapai 1 meter, setelah babat dilakukan maka dilanjutkan dengan semprot herbisida. Babat pada intinya bertujuan untuk memaksimal efek yang diberikan oleh herbisida pada tanaman.

Pemeliharaan yang intensif memberikan pengaruh pada performance persebaran diameter yang mengikuti kaidah persebaran diameter tanaman pada hutan tanaman yaitu membentuk lonceng terbalik hal ini terjadi pada petak P3 dan $\mathrm{P} 4$, pengecualian untuk petak P1 dan P2 yang bentuk kurva persebaran diameternya lebih berat ke diameter terbesar, dalam hal ini bentuk kurva mengikuti kaidah hutan tanaman untuk tanaman intoleran, kurva persebaran diameter pada hutan tanaman jenis intoleran akan berat ke kanan sedangkan hutan tanaman jenis toleran berat ke sebelah kiri. Pupuk susulan NPK 1, 2 dan 3 memberikan pengaruh pada pertumbuhan tinggi tanaman.

\section{SIMPULAN DAN SARAN}

\section{Simpulan}

Manajemen yang dilakukan terhadap tempat tumbuh di PT. PSPI adalah buka piringan, penyemprotan herbisida, dan pemberian pupuk NPK susulan. Pemeliharaan yang intensif memberikan pengaruh pada persebaran diameter yang mengikuti kaidah persebaran diameter tanaman pada hutan tanaman yaitu membentuk lonceng terbalik hal ini terjadi pada petak P3 dan P4, pengecualian untuk petak P1 dan P2 yang bentuk kurva persebaran diameternya lebih berat ke diameter terbesar, dalam hal ini bentuk kurva mengikuti kaidah hutan tanaman untuk tanaman intoleran, kurva persebaran diameter pada hutan tanaman jenis intoleran akan berat kekanan sedangkan hutan tanaman jenis toleran berat kesebelah kiri. Pupuk susulan NPK 1, 2 dan 3 memberikan pengaruh pada pertumbuhan diameter tanaman.

\section{Saran}

Saran untuk penelitian ini adalah perlu dilakukannya analisis tanah yang lengkap untuk melihat kandungan hara dan nutrisi pada tanah. Selain itu, perlu dilakukan penelitian untuk menaikkan $\mathrm{pH}$ tanah pada PT. PSPI untuk melihat pengaruh manajemen tempat tumbuh pada tanaman jika pH dalam keadaan baik. Penelitian untuk mengetahui kehilangan unsur hara pada E. pellita dan unsur hara yang dihasilkan dari serasah E. pellita juga perlu dilakukan.

\section{DAFTAR PUSTAKA}

Aprianis Y, AB Supangat, AD Barata, E Sutrisno 2010. Laporan Hasil Penelitian. Evaluasi kandungan biomassa dan dekomposisi serasah. Riau (ID): Balai Penelitian Hutan Penghasil Serat,Bangkinang-Kuok, Riau.

Barros NF, Novais RF, Neves JCL. 1990. Fertilização e correção do solo para o plantio de eucalipto. In: Barros, NF, Novais RF. (eds.) Relação SoloEucalipto, 127-186. Folha de Viçosa, Viçosa.

Bellote AFJ, Sarruge JR, Haag PH, Oliveira GD. 1980. Extração e exportação de nutrientes pel Eucalyptus grandis Hill ex-Maiden em função de idade: 1 Macronutrientes. IPEF 20: 1-23.

Daniel WT, Helms AJ, Baker FS. 1987. Prinsip-Prinsip Silvikultur. Marsono D, penerjemah; O Soeseno H, editor. Yogyakarta (ID): Gajah Mada University Press. Terjemahan dari: Prinsip-Prinsip Silvikultur. Ed ke-2.

Foth HD, Ellis BG. 1997. Soil fertility. 2nd Ed. Boca Raton: Lewis Publisher.

Gonçalves JLM. 1995. Efeito do cultivo mínimo sobre a fertilidade do solo e ciclagem de nutrientes. In: Disperati, AA, Ferreira CA, Machado, C, Gonçalves JLM, Soares RV. (eds.) 1o Seminário Sobre Cultivo Mínimo do Solo hem Florestas. Curitiba, 43-60. IPEF-CNPf-SIF-FUPEF, Brazil.

Kadri et al. 1992. Manual Kehutanan. Jakarta: Departemen Kehutanan Republik Indonesia.

Leksono B. 2010. Efisiensi Seleksi Awal pada Kebun Benih Semai Eucalyptus pellita. Jurnal Penelitian Pusat Penelitian dan Pengembangan Hutan Tanaman. 7(1): 1-13.

Mindawati N, A Indrawan, I Mansur, dan O Rusdiana. 2010. Kajian Pertumbuhan Tegakan di Sumatera Utara. Jurnal Penelitian Hutan Tanaman. 7(1): 3950.

Muliawan. 2009. Pengaruh Media Semai terhadap Pertumbuhan Eucalyptus pellita [Skripsi]. Bogor (ID): Institut Pertanian Bogor.

Mutia L. 2014. Hubungan Lebar Jalur Tanam dengan Pertumbuhan Meranti Merah (Shorea leprosula Miq) dalan Sistem Silvikultur Tebang Pilih Tanam Jalur [Skripsi]. Bogor (ID): Institut Pertanian Bogor.

Pasaribu R.A, Tampubolon. 1997. Persyaratan Teknis Bahan Baku, Air, dan Bahan Penolong untuk Industri, Kertas dan Rayon. Diktat Pelatihan Verivfikasi Eksportir Terdaftar Produk Industri Kehutanan (ETPIK). Puslitbang Teknologi Hasil Hutan, Bogor.

Quilhó T, I Miranda, H Pereira. 2006. IAWA. 27 (3): 243254.

Sihite, O. 2008. Hubungan Umur Pohon sp. dengan Kandungan Pentosan Bahan Baku Pulp pada PT Toba Pulp Lestari [Tesis]. Tidak diterbitkan. 
